\title{
The contribution of snow condition trends to future ground climate
}

\author{
David M. Lawrence · Andrew G. Slater
}

Received: 17 October 2008/ Accepted: 27 January 2009/Published online: 20 February 2009

(C) Springer-Verlag 2009

\begin{abstract}
Global climate models predict that terrestrial northern high-latitude snow conditions will change substantially over the twenty-first century. Results from a Community Climate System Model simulation of twentieth and twenty-first (SRES A1B scenario) century climate show increased winter snowfall $(+10-40 \%)$, altered maximum snow depth $(-5 \pm 6 \mathrm{~cm})$, and a shortened snow-season $(-14 \pm 7$ days in spring, $+20 \pm 9$ days in autumn). By conducting a series of prescribed snow experiments with the Community Land Model, we isolate how trends in snowfall, snow depth, and snow-season length affect soil temperature trends. Increasing snowfall, by countering the snowpackshallowing influence of warmer winters and shorter snow seasons, is effectively a soil warming agent, accounting for $10-30 \%$ of total soil warming at $1 \mathrm{~m}$ depth and $\sim 16 \%$ of the simulated twenty-first century decline in near-surface permafrost extent. A shortening snow season enhances soil warming due to increased solar absorption whereas a shallowing snowpack mitigates soil warming due to weaker winter insulation from cold atmospheric air. Snowpack deepening has comparatively less impact due to saturation of snow insulative capacity at deeper snow depths. Snow depth and snow-season length trends tend to be positively related, but their effects on soil temperature are opposing. Consequently, on the century timescale the net change in snow state can either amplify or mitigate soil warming.
\end{abstract}

D. M. Lawrence $(\bowtie)$

Climate and Global Dynamics Division,

National Center for Atmospheric Research,

P.O. Box 3000, Boulder, CO 80307, USA

e-mail: dlawren@ucar.edu

A. G. Slater

Cooperative Institute for Research in Environmental Sciences,

University of Colorado, Boulder, CO, USA
Snow state changes explain less than $25 \%$ of total soil temperature change by 2100 . However, for the latter half of twentieth century, snow state variations account for as much as $50-100 \%$ of total soil temperature variations.

Keywords Soil temperature - Snow - Climate modeling · Climate change

\section{Introduction}

Global climate models project strong warming for the Arctic during the twenty-first century as greenhouse gas concentrations rise. Terrestrial Arctic temperatures are projected to rise by between 2 and $9^{\circ} \mathrm{C}$ by 2100 depending on the greenhouse gas emissions scenario and model (Chapman and Walsh 2007). Models indicate that the ground will also warm considerably in response to the surface warming, leading to large-scale thawing of permafrost that is near the surface (Stendel and Christensen 2002; Lawrence et al. 2008a; Zhang et al. 2008). The magnitude of simulated ground warming, however, does not always relate directly to the degree of surface warming (Fig. 1). The ratio of annual mean warming of the soil at $1 \mathrm{~m}$ depth relative to near-surface air warming by 2100 , as simulated by the Community Climate System Model (CCSM3, see Sect. 3 for description of this simulation), is shown in Fig. 1c. Soil warming is less than near-surface air warming virtually everywhere (ratio $<1$ ) due to thermal damping of the warming signal by the heat capacity of the soil. The degree of thermal damping is not uniform, with soil warming ranging from $30 \%$ to over $90 \%$ of air warming depending on the geographical location.

What causes the broad range in the ratio of soil to air warming? A number of factors likely contribute such as 
(a)

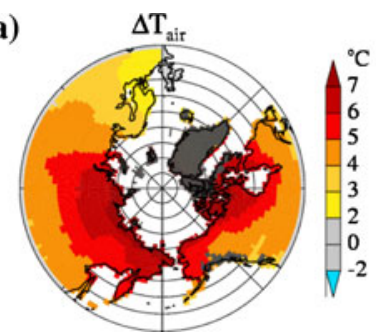

(b)

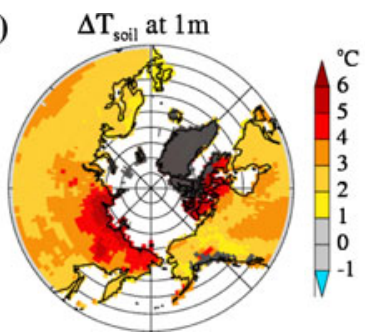

(c) $\Delta \mathrm{T}_{\text {soil }}$ at $1 \mathrm{~m} / \Delta \mathrm{T}_{\text {air }}$

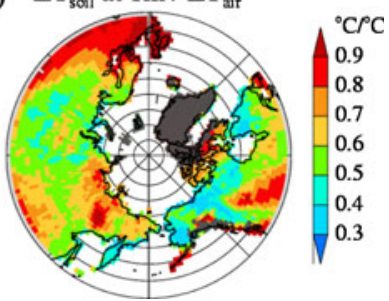

Fig. 1 Projected changes (2080-2099 minus 1950-1969) in air and soil temperature calculated from a single CCSM3 twentieth and twenty-first century (SRES A1B) integration. a annual mean $\Delta T_{\text {air. }}$ b annual mean $\Delta T_{\text {soil }}$ at $1 \mathrm{~m}$. $\mathbf{c}$ Ratio of annual mean $\Delta T_{\text {soil }}$ at $1 \mathrm{~m}$ over annual mean $\Delta T_{\text {air }}$. Dark gray in all maps indicates grid box is at least partly composed of glacier land cover type with perennial snow cover spatial differences in the thickness of the insulating organic mat, the overlying vegetation type (e.g., forests with extensive shading versus tundra without), and the column soil water content (more water yields higher heat capacity and slower response). One of the most important factors, though, is likely to be snow. Changes in the magnitude and timing of snowfall, snow depth, and snow-season length can all modulate the soil's response to surface warming (Osterkamp and Romanovsky 1999). Snow is a strong insulator of the ground and substantially influences the ground thermal regime (Goodrich 1982; Stieglitz et al. 2001; Zhang 2005). The thermal offset between air and ground temperature can be quite large. At Ivotuk, Alaska $\left(68^{\circ} \mathrm{N}, 156^{\circ} \mathrm{E}\right)$ for example, mean annual air temperature is $-10.3^{\circ} \mathrm{C}$ while mean ground surface temperature is $-1.4^{\circ} \mathrm{C}$ (Romanovsky 2001). Under a warming climate, a deepening of the winter snowpack, therefore, could amplify soil warming while a shallowing of the snowpack could mitigate it. Since a snow-covered surface reflects a much large portion of the incoming solar radiation than a snow-free surface, a lengthening or shortening of the snowseason will alter how much incoming solar energy is absorbed by the ground, also affecting soil temperatures. Prior studies, both modeling and observation based, suggest that soil temperature change (at 10-20 m depth) over the latter part of the twentieth and early part of the twentyfirst century can be attributed roughly equally to air temperature and snow depth trends or variations (Zhang et al. 2001; Stieglitz et al. 2003; Osterkamp 2007b). Osterkamp (2007a) concludes that modeling studies are required to assess the relative role of snow versus air temperature effects on soil temperature trends.

Observed trends in snow over the latter part of the twentieth century have been fairly modest. Annual mean Northern Hemisphere snow-covered area (SCA) has decreased at a rate of -0.33 million $\mathrm{km}^{2}$ decade ${ }^{-1}$ or $-1.4 \%$ decade $^{-1}$ (1966-2005; Lemke et al. 2007) with highest rates of decrease $\left(-0.80\right.$ to -1.10 million $\mathrm{km}^{2}$ decade $^{-1}$ ) apparent in spring and early summer. This decrease in SCA is consistent with observed decreases in snow season length by $\sim 5-6$ days decade $^{-1}$ over the period 1972-2000 (Dye
2002). Models qualitatively capture the observed SCA trends $\left(-0.27\right.$ million $\mathrm{km}^{2}$ decade $^{-1}$ in annual mean SCA with CCSM3 over the same 1966-2005 period). CCSM3 projects an increase in the rate of SCA loss from -0.27 to -0.36 million $\mathrm{km}^{2}$ decade $^{-1}$ in the twenty-first century. Observed trends in snow depth and snow water equivalent (SWE) are not spatially coherent with regions of increasing, decreasing, and flat trends apparent in more limited snow depth data.

Although observed snow trends have, to this point, not been particularly large, future snow trends, which are a function of surface air temperature, snowfall rates, circulation and radiative forcing, are expected to grow over the twenty-first century. Most GCMs indicate that across much of the northern hemisphere mid- and high-latitudes, winter snowfall (and precipitation more generally) will increase substantially (Meehl et al. 2007b; Räisänen 2008)—the increase in precipitation appears to be predominantly associated with greater moisture capacity of the warmer air rather than large-scale circulation changes (Cassano et al. 2007). More winter snowfall will not necessarily translate to more snow on the ground, however. Räisänen (2008) analyzed simulated changes in future snow conditions across 20 global climate models available in the Coupled Model Intercomparison Project (CMIP3) archive (Meehl et al. 2007a). In that study, Räisänen showed that the CMIP3 models predict that, by the year 2100, mean winter (NDJFM) snowfall rates will increase by between 15 and $45 \%$ but also that the snow season will shorten from both ends across most of the northern mid- and high-latitudes. Due to the competing processes of increasing snowfall, a shorter snow accumulation season, and mid-winter snow melt and compaction, the March SWE signal exhibited a more mixed response in the CMIP3 models, even with consistently higher snowfall. SWE generally increased in colder regions such as Siberia, northern Alaska, and northern Canada and decreased elsewhere.

The degree of future snow changes is important because snow depth, snow density, and snow cover duration strongly affect ground climate (Zhang 2005) and therefore permafrost, ecology, and biogeochemical cycling (Sturm 
et al. 2005). A shallower winter snowpack provides less insulation from cold winter air temperatures, thereby cooling the soil, whereas a deeper snowpack provides more insulation resulting in warmer soils. The influence of changes in snow season length is more complex. Earlier spring snow melt enhances absorption of solar radiation at the surface and lengthens the soil heating season. In the autumn, a delay of snow onset can result in either warming or cooling of the ground. A delay due to warmer air temperatures and a later date in which the air temperature drops below freezing would correspond to a reduction in autumnal soil cooling (or a mean warming effect). Alternatively, if the delayed snow onset is primarily due to a change in weather patterns resulting in less snowfall, then the later snow-season start date could lead to cooler soil temperatures since the lack of snow cover means that the ground is not insulated from the cold autumnal air.

In this study, we assess how changes in snowfall, snow depth, and snow-season length simulated in a twentieth and twenty-first (A1B SRES emissions scenario) century integration of the Community Climate System Model (CCSM3) contribute to the simulated evolution of soil temperature over that same period. In Sect. 2, we introduce the Community Land Model (CLM), which we use to evaluate the snow-soil temperature relationship. In Sect. 3, we present data on projected snow changes in CCSM3. In Sect. 4 we present results from a series of numerical experiments that are designed to assess and unravel how changes in snowfall, snow depth, and snow-season length affect the evolution of soil temperatures across the terrestrial Arctic. We conclude with a discussion and summary in Sects. 5 and 6.

\section{Model description}

The Community Land Model (CLM, Oleson et al. 2004) is a state-of-the-art process-based model of the land-surface that serves as the land component of the CCSM (Collins et al. 2006). It calculates heat and radiation fluxes at the land-atmosphere interface, as well as temperature, humidity, and soil thermal and hydrologic states-including explicit treatment of soil freeze/thaw processes. Sub-grid scale surface heterogeneity is represented through satellitederived fractional coverage of lakes, wetland, bare soil, glacier, and vegetation consisting of up to four plant functional types in each grid box. For this study, we use the same version of CLM as the one described in Lawrence et al. (2008a). This version is based on CLM3.5 (Oleson et al. 2008; Stöckli et al. 2008) with additional modifications that improve permafrost dynamics. CLM3.5 alleviates a number of biases in the representation of the hydrological cycle in CLM3 including CLM3's poor partitioning of evapotranspiration into transpiration, soil evaporation, and canopy evaporation (Lawrence et al. 2007) and CLM3's too dry and weakly varying soil moisture. The modifications that improve permafrost dynamics include a spatially explicit representation of the thermal and hydrologic properties of organic soil (Lawrence and Slater 2008) and a deepening of the soil column to $50 \mathrm{~m}$ (15 layers of exponentially increasing thickness ranging from $1.7 \mathrm{~cm}$ thick at the surface to $20 \mathrm{~m}$ thick for the deepest layer) to capture the thermal inertia provided by deep ground (Lawrence et al. 2008a). The model can represent talik formation and the concomitant impact on ground heat flux (Lawrence et al. 2008b). Given observed forcing, the model provides an unbiased simulation of snow mass across most of the Arctic (Slater et al. 2007) and the updated soil component reasonably simulates observed soil temperature-depth-annual cycle relationships for tested locations in Siberia and Alaska (Nicolsky et al. 2007, Lawrence et al. 2008a).

The snow scheme in CLM3.5 represents up to 5 snow layers and represents processes such as accumulation, melt, compaction, aging, and water transfer across layers (see Oleson et al. (2004) for complete technical description of the snow model). Wind redistribution of snow is not represented. Snow thermal conductivity is based on Jordan (1991):

$$
\begin{aligned}
\lambda_{\text {sno }}= & \lambda_{\text {air }}+\left(7.75 \times 10^{-5} \rho_{\text {sno }}+1.105 \times 10^{-6} \rho_{\text {sno }}^{2}\right) \\
& \times\left(\lambda_{\text {ice }}-\lambda_{\text {air }}\right)
\end{aligned}
$$

where $\lambda_{\text {sno }}, \lambda_{\text {ice }}$, and $\lambda_{\text {air }}$ are the thermal conductivities of snow, ice, and air, respectively and $\rho_{\text {sno }}$ is the snow density (SWE/SNWDP where SNWDP is the snow depth). As snow density increases, due to destructive metamorphism, overburden pressure, or melting/refreezing, thermal conductivity increases, reducing the insulative capacity of snow. Typical simulated $\lambda_{\text {sno }}$ values range between 0.15 and $0.45 \mathrm{~W} \mathrm{~m}^{-1} \mathrm{~K}^{-1}$ with a clear increase in $\lambda_{\text {sno }}$ as the snow season progresses and the snowpack gets denser. Due to the high albedo of snow relative to vegetation or bare ground, grid cell albedo is strongly altered by snow cover. Snow cover fraction (SCF) is determined according to

$\mathrm{SCF}=\frac{\mathrm{SNWDP}}{10 z_{0 \mathrm{~m}, \mathrm{~g}}+\mathrm{SNWDP}}$

where $z_{0 \mathrm{~m}, \mathrm{~g}}=0.01$ is the roughness length for soil $(\mathrm{m})$. Snow burial fraction (SBF), or the vertical fraction of vegetation that is covered by snow is

$$
\begin{aligned}
& \mathrm{SBF}=\frac{\mathrm{SNWDP}-z_{\text {bot }}}{z_{\text {top }}-z_{\text {bot }}} \\
& \quad \text { for } \mathrm{SNWDP}-z_{\text {bot }} \geq 0 ; 0 \leq \mathrm{SBF} \leq 1
\end{aligned}
$$


where $z_{\text {top }}$ and $z_{\text {bot }}$ are the canopy top and bottom heights which vary according to plant functional type.

During a preliminary evaluation of the experimental protocols used in this study (see Sect. 4), we identified two minor errors in the snow model that were corrected prior to completing the final experiments. The first correction is to the calculation of snow compaction rates due to overlying snow mass. In CLM3.5, snow compaction rates due to overburden are calculated by summing the mass of all snow layers above the compacting layer. This method does not take into account the contribution of the snow mass within the compacting layer to the total overburden snow compaction. We correct this by adding half of that layer's weight to the total overburden mass. The second minor problem is that when a snow layer splits (e.g. when new snow accumulation is sufficient to require an additional snow layer; a snowpack in CLM contains up to five snow layers, depending on total snow depth), the same snow temperature of the original single layer is applied to both layers. This method conserves energy but it alters the vertical temperature profile of the snowpack, resulting in an unrealistic spike in the temperature of the uppermost soil layer as the snowpack temperature profile comes into a new equilibrium. We correct this by maintaining the original snowpack temperature profile by adjusting snow temperatures in the two layers to lie as close as possible to the original profile while still conserving total snowpack energy. These two corrections result in a $5-10 \%$ reduction in the simulated annual maximum snow depths-slightly higher snow compaction rates lead to slightly shallower snowpacks-and eliminate unrealistic snow and soil temperature shifts that occur immediately after a snow layer splitting event. The shallower snowpacks and correspondingly weaker snow insulation results in cooler soil temperatures by up to $0.5^{\circ} \mathrm{C}$ in the most impacted locations.

\section{Projected future changes in snow properties in CCSM3}

We begin by analyzing a CCSM3 simulation of the twentieth and twenty-first centuries for changes in snow properties such as snowfall rates (SNWFLL), snow depth (SNWDP), and snow-season length as well as changes in air $\left(T_{\text {air }}\right)$ and soil $\left(T_{\text {soil }}\right)$ temperatures. The original fully coupled ocean-atmosphere-land-sea-ice simulation was one of an ensemble of CCSM3 simulations conducted in support of CMIP3 (Meehl et al. 2007a) and that featured heavily in the Intergovernmental Panel on Climate Change Fourth Assessment Report (IPCC AR4). In the simulation assessed here, the twentieth century period was forced with observed natural and anthropogenic forcings (greenhouse gases, sulfate aerosols, volcanoes, ozone, solar, halocarbons, and black carbon aerosols) and the twenty-first century period was forced by the mid-range SRES A1B emission scenario (Meehl et al. 2006). The simulation was conducted at T85 resolution $\left(\sim 1.4^{\circ}\right.$ latitude $\times 1.4^{\circ}$ longitude). High temporal resolution (daily) snow fields, which we require for this study, were not archived for any of the original coupled integrations. Fortunately, for one member of the eight-member ensemble, a full set of 6-hourly data suitable to force the land model (precipitation, air temperature, downward solar and longwave radiation, surface wind speed, specific humidity, and air pressure) was archived (note that this data was only archived for the A1B scenario which is why this scenario is used for this study). With this forcing data, interpolated to the 30-min CLM time step, we regenerate daily snow fields for two 20-year periods, 1950-1969 and 2080-2099. We subjectively select the period 1950-1969 as our baseline because that corresponds to the period when snow properties and soil temperatures begin to exhibit clearly detectable trends in the coupled simulation. The 'regenerated' monthly climatological snow properties are qualitatively similar to those from the original coupled simulation.

Maps of mean changes (2080-2099 minus 1950-1969) in snow properties including winter snowfall, annual maximum snow depth, snowpack thermal conductivity, annual mean SCF, date of autumn snow onset, and date of spring snow melt are shown in Fig. 2. Across most of the terrestrial northern high-latitudes, the CCSM3 projects winter (November to March, NDJFM) snowfall increases of between 25 and $100 \mathrm{~mm} \mathrm{SWE}$, which corresponds to $10-40 \%$ more snow. This level of increase is consistent with other CMIP3 models (Räisänen 2008). Winter snowfall decreases across northern Europe as winter air temperatures rise enough there to convert some winter snowfall to rain. Increased snowfall does not necessarily result in a deeper snowpack (Fig. 2b). Over Alaska and northern Canada, the maximum snow depth shallows even while snowfall increases due in part to a much shorter overall snow season (25-45 days shorter; Fig. 2e, f) as well as additional autumn and mid-winter melt and compaction. Snow depth increases over much of eastern Siberia where snowfall increases and the snow season shortens more modestly ( 0 to 25 days). The shorter snow season is reflected as a reduction in the shoulder season (April, May, September, October) snow cover fraction (SCF, fraction of a grid cell covered with snow Fig. 2d). Snow thermal conductivity increases slightly in most locations (Fig. 2c), especially in warmer regions where conditions can lead to more snow compaction, denser snow, and therefore higher thermal conductivities. In Table 1 we list the mean and 
(a)

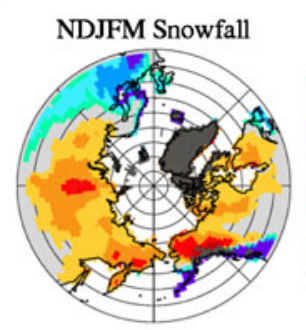

(d)

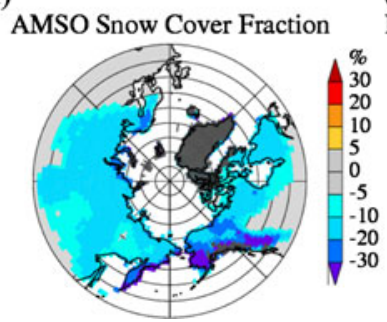

(b)

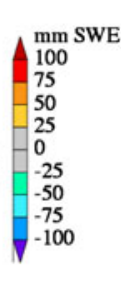

(e)
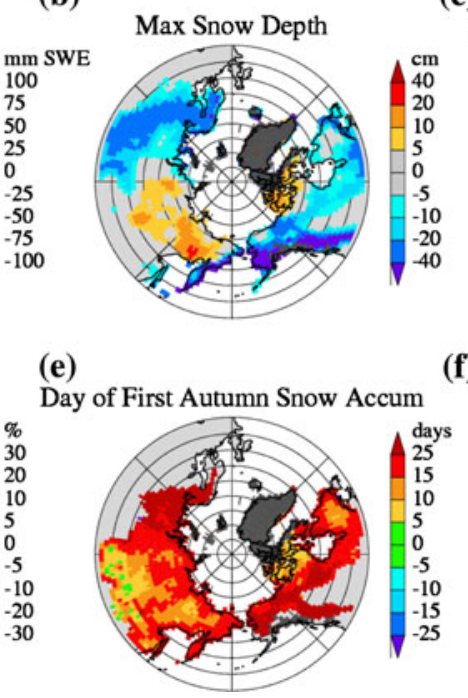

(f) (c)
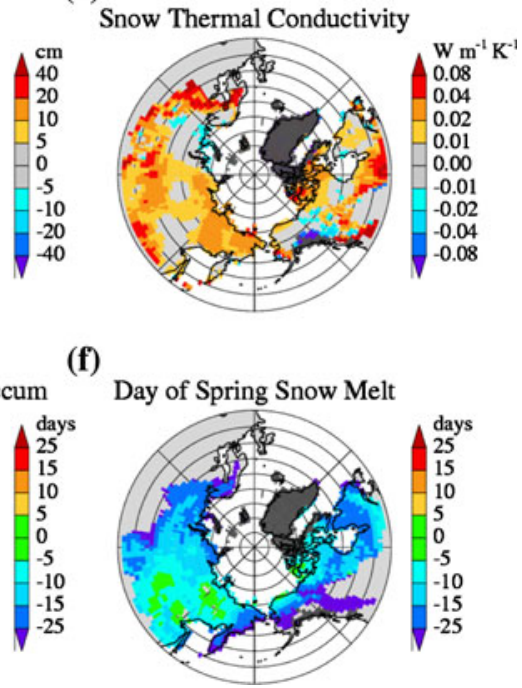

Fig. 2 Projected changes (2080-2099 minus 1950-1969) in climatological snow-related properties calculated from a single CCSM3 twentieth and twenty-first century (SRES A1B) integration. a Winter (November-March; NDJFM) snowfall in snow water equivalent. b Annual maximum snow depth. c Winter snow thermal conductivity. d Shoulder season (April, May, September, October; AMSO) snow cover fraction. e Day of year when autumn snow accumulation reaches $10 \mathrm{~cm}$, grid cells with $<90$-day or $>300$-day snow season in either 1950-1969 or 2080-2099 are masked out in light grey. f Day of year when spring snow melt brings snow depth below $10 \mathrm{~cm}$, masking as in e. Dark grey in all maps indicates grid box is at least partly composed of glacier land cover type with perennial snow cover

Table 1 Snow and temperature change statistics

\begin{tabular}{lcclllrrr}
\hline & $\begin{array}{l}T_{\text {air,mn }} \\
\left({ }^{\circ} \mathrm{C}\right)\end{array}$ & $\begin{array}{l}T_{\text {air,NDJFM }} \\
\left({ }^{\circ} \mathrm{C}\right)\end{array}$ & $\begin{array}{l}\text { SNWFLL } \\
(\mathrm{mm})\end{array}$ & $\begin{array}{l}\text { SNWDP } \\
(\mathrm{cm})\end{array}$ & $\begin{array}{l}\lambda_{\text {NDJFM }} \\
\left(\mathrm{W} \mathrm{m} \mathrm{m}^{-1} \mathrm{~K}^{-1}\right)\end{array}$ & $\begin{array}{l}\text { Spring melt date } \\
(\text { days })\end{array}$ & $\begin{array}{l}\text { Autumn onset date } \\
(\text { days })\end{array}$ & $\begin{array}{l}\text { SCF } \\
(\%)\end{array}$ \\
\hline Mean & +5.8 & +8.0 & +46.5 & -5.2 & +0.015 & -14 & +20 \\
St. Dev. & 1.2 & 2.1 & 17.7 & 5.7 & 0.017 & 7 & 9.5 \\
\hline
\end{tabular}

Mean and standard deviation of a number of snow and temperature fields for 2080-2099 minus 1950-1969. Mean is average over the 2,328 grid points with a distinct snow season (e.g. colored area in Fig. 2e, f). Standard deviation is calculated across these grid points

standard deviation of the 2080-2099 minus 1950-1969 change for a variety of snow and temperature fields. The means and standard deviations are calculated over the 2,328 grid points with a 'distinct' snow season in both reference periods. We subjectively define a 'distinct' snow season as continuous snow cover of more than 90 days and less than 300 days duration (e.g. focuses on locations with extended snow cover while excluding locations with sporadic winter snow cover or perpetual snow cover such as glacier points; colored areas in Fig. 2e, f).

Note that the specific regionality of snow projections apparent in these maps should be interpreted with caution. The climate change projection and its impact on snow properties shown in the maps in Figs. 1 and 2 are obtained from a single simulation with a single model and therefore are not robust regional projections of future snow characteristics. Instead, these maps provide indications of the form of snow changes that are possible under warming and, particularly with respect to snow-soil temperature relations, provide information as to how snow changes modulate the soil temperature response to air warming.

\section{Controlled snow experiments}

The projected changes in snow properties described in the previous section and shown in Fig. 2 motivate two sets of numerical experiments designed to diagnose how changes in snow properties affect the century-scale evolution of Arctic soil temperatures. The first set of experiments, controlled snowfall experiments, is designed to assess how much the steady increase in Arctic snowfall contributes to soil warming. The second set of experiments, prescribed snow depth and snow-season length experiments, is designed to determine how simulated changes in snow depth and snow-season length, individually and together, affect soil temperature trends over the late twentieth and twenty-first centuries. 
4.1 Controlled snowfall trend experiments

\subsubsection{Experimental design}

As noted above, winter snowfall is projected to increase substantially during the twenty-first century over most of the Arctic land area (Fig. 2a). We conduct two offline experiments, a control experiment and a constant climatological snowfall experiment, to evaluate what contribution the increased snowfall has on simulated future snow depth and soil temperature. For the constant snowfall experiment (MID20C_FALL; names and descriptions of all experiments in this study are listed in Table 2), we maintain 1950-1969 climatological monthly snowfall throughout the 150-year (1950-2099) simulation by scaling the forcing data (forcing data taken from CCSM3 fully coupled simulation, see Sect. 3) snowfall rate, SNWFLL ( $y, m, t)$, at every time step according to:

SNWFLL_const $(y, m, t)$

$$
=\left(\frac{\overline{\operatorname{SNWFLL}_{1950-1969}(m)}}{\operatorname{SNWFLL}(y, m)}\right) \operatorname{SNWFLL}(y, m, t)
$$

where $y$ is the year, $m$ is the month, $t$ is the time step within that month, $\overline{\text { SNWFLL }_{1950-1969}(m)}$ is the monthly climatological 1950-1969 snowfall, and $\operatorname{SNWFLL}(y, m)$ is the mean monthly snowfall for a particular year and month. To avoid unreasonable snowfall forcing where $\operatorname{SNWFLL}(y, m)$ approaches or is equal to zero, we restrict the $\operatorname{SNWFLL}(y$, $m, t$ ) multiplier to be $\leq 10$.
We compare this simulation with a control simulation where the forcing data is unchanged except that the monthly snowfall forcing time series is smoothed with a 9 year running mean to filter out interannual snowfall variability. By smoothing the snowfall forcing time series, we eliminate interannual snowfall variability as a potential source of difference between the simulations, thereby focusing on the role of snowfall trends. This experiment is referred to as TRND_FALL (Table 2).

\subsubsection{Results}

For illustration, sample plots of accumulated snowfall (September-August) and the snow depth annual cycle are shown in Fig. 3 for both the TRND_FALL and MID20C_FALL experiments for the periods 1950-1969 and 2080-2099. Had snowfall not increased, we would have seen a substantial decrease in snow depths due to enhanced ablation in the warmer end of twenty-first century climate. Maximum snow depth in the Alaskan Arctic would have almost been halved and Eastern Siberia's snow depths would be reduced by $30 \%$ (dashed vs dotted lines in Fig. 3). As emphasized above, an increase in snowfall does not necessarily lead to deeper winter snow depths. In the case of the Alaskan Arctic, warmer air temperatures hinder snow accumulation during September and October. This early season accumulation deficit is maintained through the winter, even with the greater snowfall implying that the extra snowfall is offset by increased melt and compaction. Note that although our algorithm (Eq. 4) attempts to maintain monthly snowfall at 1950-1969 levels throughout

Table 2 List of experiments and their description

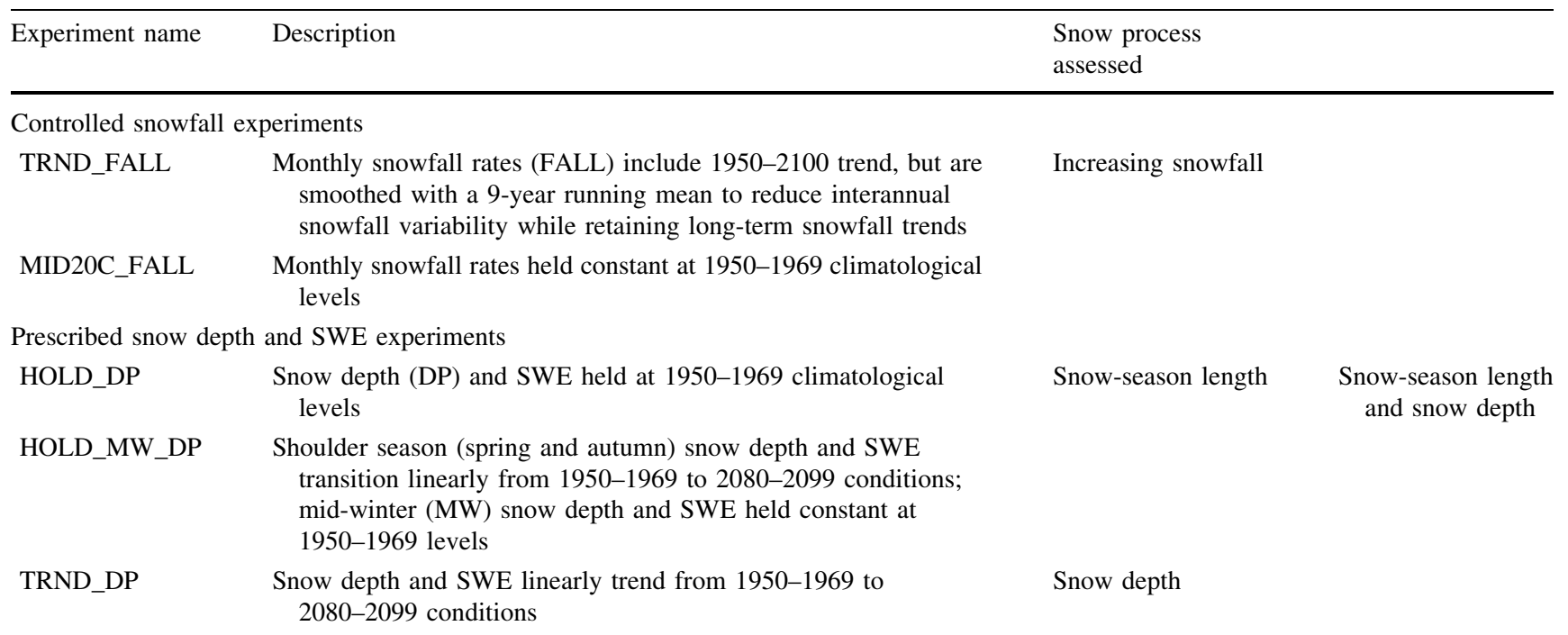

All experiments are offline CLM3.5 (see text for changes from released version of CLM3.5) experiments forced with 6-hourly meteorological forcing taken from a CCSM3 A1B integration (as in Lawrence et al. 2008a) 
Fig. 3 Accumulated snowfall and snow depth annual cycle for TRND_FALL and MID20C_FALL experiments for the periods $1950-1969$ and 2080-2099. Note that the accumulated snowfall and snow depth annual cycle for MID20C_FALL (1950-1969) are almost identical to those in TRND_FALL and therefore are not plotted
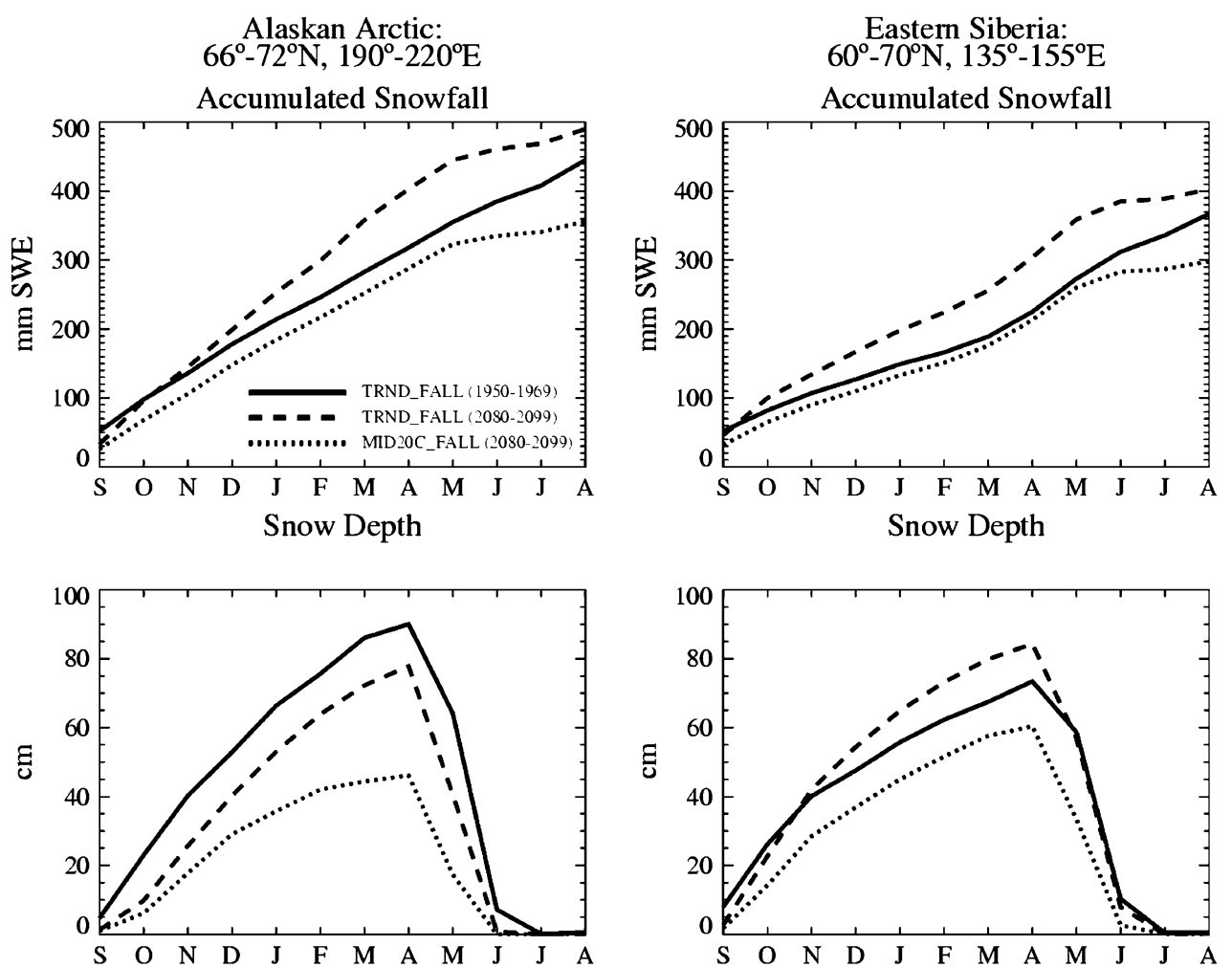

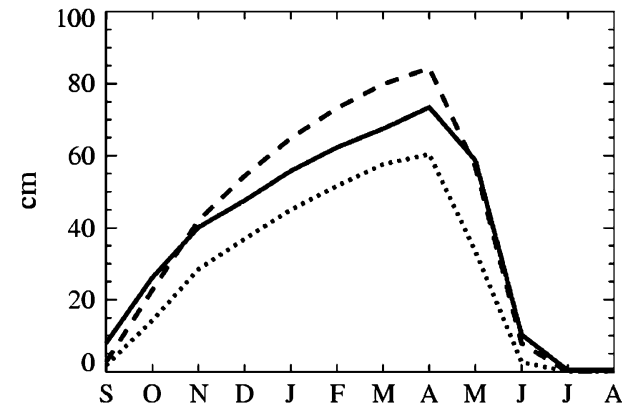

the MID20C_FALL experiment, the warmer climate at the end of the twenty-first century no longer supports any snowfall in late spring and summer and therefore precipitation that fell as snow during the 1950-1969 period has to fall as rain during 2080-2099. Consequently, accumulated snowfall at the end of the snow year is slightly lower in 2080-2099 compared to 1950-1969.

Recall that the impact of climate change (warming plus snowfall changes) on snow depth is varied, as evidenced by the both positive and negative $\mathrm{SNWDP}_{\max }$ changes shown in Fig. 2b. With the controlled snowfall experiment, we can isolate to what extent snowfall increases affect the snowpack (Fig. 4a). Unsurprisingly, increasing snowfall generates substantially deeper snowpacks than would have occurred in a warmer climate but without more snowfall. Or, put another way, without rising winter snowfall, the shallowing of the snowpack due to warming would be much more severe than that apparent in Fig. 2 b.

The deeper winter snowpack in TRND_FALL more effectively insulates the ground from cold atmospheric air, maintaining heat gained during the summer and therefore helping annual mean soil temperatures $\left(T_{\text {soil,mn }}\right)$ to warm more than in MID20C_FALL (Fig. 4b). Differences in $T_{\text {soil,mn }}$ range from about $+0.25^{\circ} \mathrm{C}$ to $+1.5^{\circ} \mathrm{C}$, which corresponds to roughly $10-30 \%$ of the total soil warming from 1950 to 2100 . $T_{\text {soil,max }}$ is more strongly affected with differences between TRND_FALL and
MID20C_FALL exceeding $+2^{\circ} \mathrm{C}$ over extensive areas of Siberia and in isolated locations in Alaska and Canada, corresponding to more than $40 \%$ of the total $T_{\text {soil,max }}$ warming.

Why does the deeper snowpack in TRND_FALL result in so much more $T_{\text {soil,max }}$ warming relative to $T_{\text {soil,mn }}$ warming? The difference appears to relate primarily to imperfections in soil temperature as a diagnostic, especially for situations where $T_{\text {soil }}$ warms to near $0^{\circ} \mathrm{C}$. At this temperature, a large portion of the energy absorbed by the ground is devoted to melting ice rather than increasing $T_{\text {soil. }}$. Once the majority of soil ice in the upper part of the column has melted and especially when a talik (a talik is a layer of perpetually unfrozen ground located between seasonally frozen soil above and permafrost below) forms, soil temperatures can warm up much more rapidly in summer (Lawrence et al. 2008b). Soil heat content (SHC) is an alternative diagnostic that is useful because it circumvents the lack of clarity at temperatures near $0^{\circ} \mathrm{C}$ since it accounts for both soil temperature and the heat contributions of liquid and ice water (liquid water holds considerably more heat than ice). Figure $4 \mathrm{f}$ shows the percentage of the annual mean column SHC change ( $\% \Delta \mathrm{SHC}$ ) that can be attributed to increased snowfall. The magnitude and spatial pattern of $\% \Delta \mathrm{SHC}$ agrees more closely with $\% \Delta T_{\text {soil,max }}$ than $\% \Delta T_{\text {soil,mn }}$ (Fig. $4 \mathrm{~d}-\mathrm{f}$ ) which suggests that the impact of increasing snowfall on $T_{\text {soil,max }}$ may be more representative of its full impact on ground 
TRND_FALL - MID20C_FALL (2080-2099)

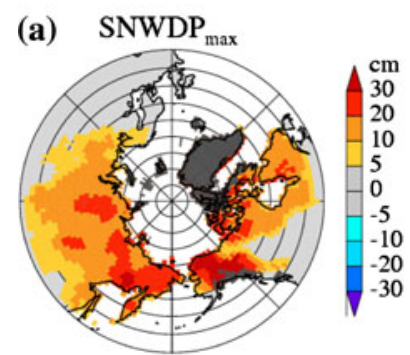

(d) $\% \Delta \mathrm{T}_{\text {soil,mn }}$ at $1 \mathrm{~m}$

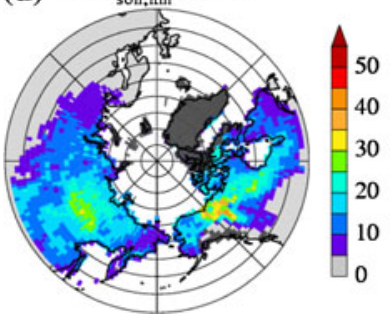

(b) $\mathrm{T}_{\text {soil,mn }}$ at $1 \mathrm{~m}$

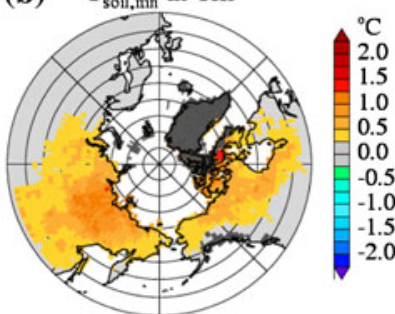

(e) $\% \Delta \mathrm{T}_{\text {soil,max }}$ at $1 \mathrm{~m}$

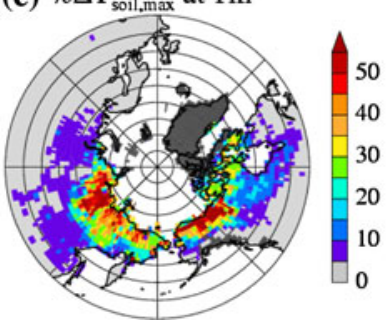

(c) $\mathrm{T}_{\text {soil,max }}$ at $1 \mathrm{~m}$

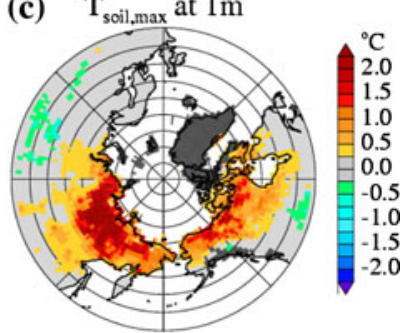

(f) $\% \Delta \mathrm{SHC}_{\mathrm{mn}}$

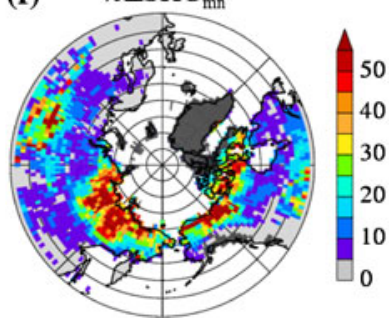

Fig. 4 Impact of projected increases in snowfall on simulated snow depth, soil temperature, and soil heat content. Differences at 20802099 in (a) annual maximum snow depth, (b) annual mean $T_{\text {soil }}$ at $1 \mathrm{~m}$ depth, and (c) annual maximum $T_{\text {soil }}$ at $1 \mathrm{~m}$ depth between TRND_FALL (snowfall forcing includes trends) and MID20C_FALL (snowfall held at climatological 1950-1969 rates). Percentage of (d)

thermal state. It should be noted, though, that SHC is also an imperfect diagnostic as it is sensitive to changes in soil water content (a dry soil contains less heat than a wet soil at the same temperature). Across most of the Arctic, however, soil water contents are not substantially affected by the lower snowfall in MID20C_FALL because the reduced infiltration of snow melt water is compensated for by lower evapotranspiration rates. However, for the region that encompasses Kazakhstan and south central Russia $\left(45-55^{\circ} \mathrm{N}, 45-90^{\circ} \mathrm{E}\right)$, the lower snowfall in MID20C_ FALL produces significantly drier soils by 2100 which strongly affects SHC (e.g., high \% $\triangle \mathrm{SHC}$ ), but has relatively little impact on snow depth and consequently relatively little impact on $T_{\text {soil }}$.

To enable comparison back to our previous assessments of projected near-surface permafrost degradation (Lawrence and Slater 2005; Lawrence et al. 2008a), we consider the impact of snowfall increase on the projected rate of contraction of near-surface permafrost extent (Fig. 5). We define near-surface permafrost extent as the integrated area in which permafrost-ground that remains below $0^{\circ} \mathrm{C}$ for two or more consecutive years-is present in at least one soil layer within the upper $3.5 \mathrm{~m}$ (10 model soil layers). In the absence of the snowfall increase predicted in CCSM3, the shallower and less insulative snowpacks in MID20C_FALL maintain cooler soils, resulting in $\sim 1.5$ million $\mathrm{km}^{2}(\sim 16 \%)$ less contraction of near-surface permafrost extent. annual mean $T_{\text {soil }}$, (e) annual maximum $T_{\text {soil }}$, and (f) annual mean soil heat content (SHC) change (1950-1969 to 2080-2099) attributable to projected increases in snowfall rates. Dark gray in all maps indicates grid box is at least partly composed of glacier land cover type with perennial snow cover

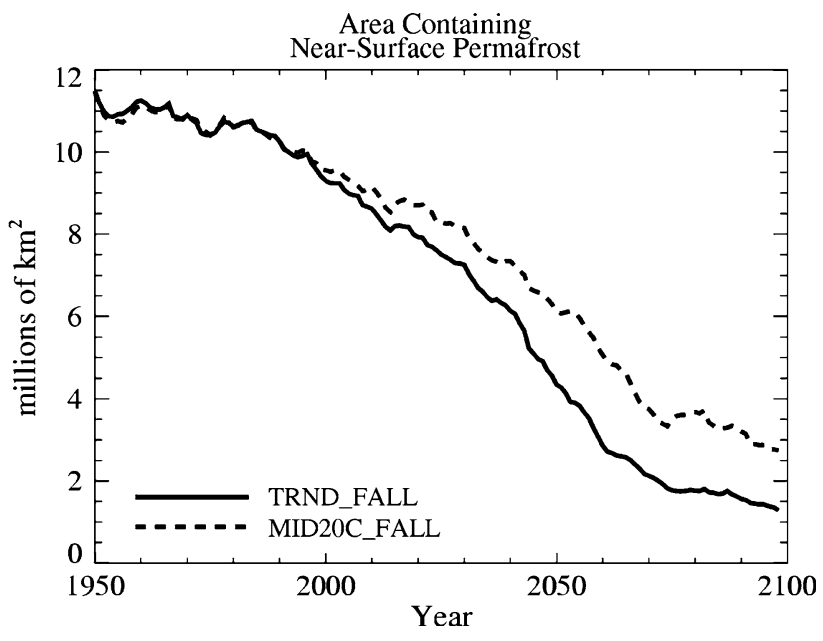

Fig. 5 Time series of the integrated area (north of $45^{\circ} \mathrm{N}$ ) in which permafrost is present within the top $3.5 \mathrm{~m}$ of soil for the TRND_FALL and MID20C_FALL experiments

\subsection{Controlled snow depth and snow-season length trend experiments}

\subsubsection{Experimental design}

We evaluate the impact of projected twenty-first century snow depth and snow-season length changes through a set of three prescribed-snow experiments in which we overwrite simulated SNWDP and SWE at every time step 
with experiment-specific snow conditions, as described below. All three offline simulations are forced with identical 6-hourly data from a fully coupled CCSM3 A1B integration (Sect. 3). For the first simulation, we hold SNWDP and SWE at simulated climatological (1950-1969) levels (this simulation is referred to as HOLD_DP; see Table 2 for names and descriptions of experiments). Since snow conditions are not permitted to evolve, snow insulative and reflective capacities are maintained at 1950-1969 levels throughout the 150-year simulation.

In the second experiment, we maintain mid-winter SNWDP and SWE at 1950-1969 levels, but for the shoulder seasons we prescribe a linear transition from 1950 to 1969 conditions to 2080-2099 conditions. Specifically, for each grid point we prescribe the snow depth for each day (d) and year of the simulation according to:

$$
\begin{aligned}
& \operatorname{SNWDP}(d, y)=\frac{150-y}{150}\left[\operatorname{SNWDP}_{1950-1969}(d)\right. \\
& \left.-\operatorname{SNWDP}_{2080-2099}(d)\right]+\operatorname{SNWDP}_{2080-2099}(d) \\
& \operatorname{SNWDP}_{2080-2099}(d) \leq 10 \mathrm{~cm}
\end{aligned}
$$

$\operatorname{SNWDP}(d, y)=\operatorname{SNWDP}_{1950-1969}(d)$

$$
\operatorname{SNWDP}_{2080-2099}(d)>10 \mathrm{~cm}
$$

Here, $y$ is number of years beyond 1950 and SNWDP $_{1950-1969}$ and SNWDP ${ }_{2080-2099}$ are the climatological daily snow depths for the respective periods. Analogous expressions are used to derive the $\operatorname{SWE}(d, y)$ time series. This experiment, which isolates the impact of changes in snow-season length on ground climate, is referred to as HOLD_MW_DP for hold mid-winter snow depth.

For the third experiment, we prescribe a linear transition from 1950 to 1969 snow conditions to 2080-2099 conditions, all $\operatorname{SNWDP}(d, y)$ and $\operatorname{SWE}(d, y)$ are prescribed according to Eq. 5 for all days of the year. This experiment (TRND_DP, for snow depth trend), when compared to HOLD_MW_DP, reveals the impact of mid-winter snow depth changes on soil temperatures. For illustration, sample snow depth annual cycles at the year 2099 are shown for each experiment in Fig. 6.

\subsubsection{Results}

Differences in 2080-2099 winter snow depth (NDJFMA) and spring and autumn SCF are shown in Fig. 7 for HOLD_MW_DP-HOLD_DP, TRND_DP-HOLD_MW_ DP, and TRND_DP-HOLD_DP. Shoulder season SCF is a proxy for snow-season length; a decrease in SCF corresponds to a shortening of the snow season. As expected (and by design), most of the changes in SCF are seen in the differences between HOLD_MW_DP and HOLD_DP
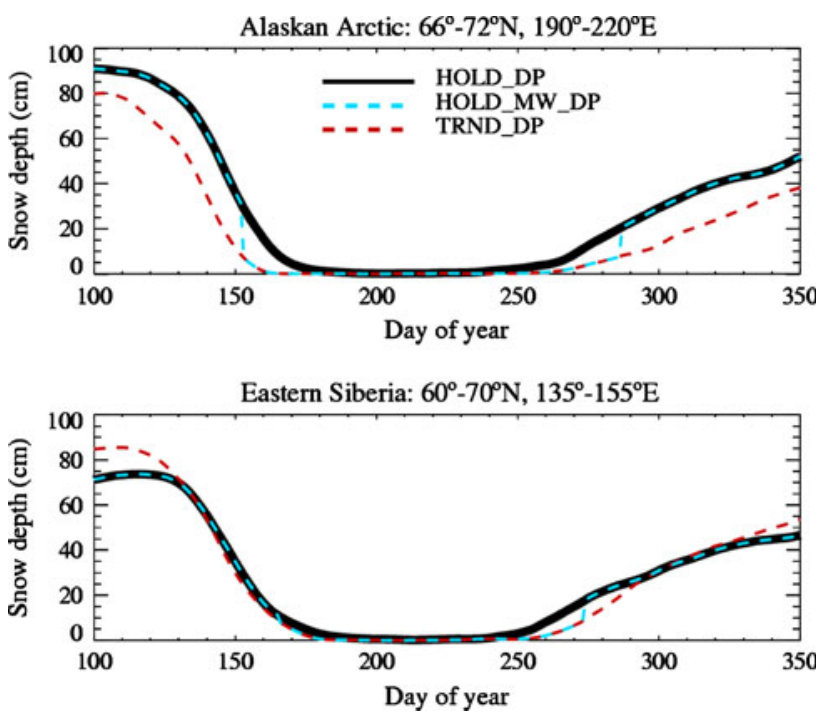

Fig. 6 Annual cycle of prescribed snow depth for HOLD_DP, HOLD_MW_DP, and TRND_DP experiments (see Table 2 for experiment descriptions). Data shown is for the final year of the simulation, year 2099. The black line is the climatological snow depth (1950-1969) that is the starting snow depth for each of the three experiments and which is also the snow depth at 2099 for HOLD_DP. For HOLD_MW_DP and TRND_DP, the prescribed snow depth transitions linearly from the climatological 1950-1969 conditions to 2080-2099 conditions. Note that for presentation purposes, we only show days $100-350$ of the annual cycle

while changes in snow depth are apparent in the differences between TRND_DP and HOLD_MW_DP, thus confirming that the simulated snow state has been successfully overwritten with the prescribed snow state as intended. Note that since SCF is a function of snow depth (see Oleson et al. 2004), the trends in snow depth prescribed in TRND_DP generate additional small spring and autumn SCF decreases.

Based on these experiments, we can now evaluate individually and together how projected changes in snow depth and snow-season length contribute to future soil temperature change (Fig. 7). In general, a shorter duration snow season warms the ground (Fig. 7c, left panel). Earlier spring snow melt and later autumn snow accumulation lowers the albedo and allows stronger solar absorption and therefore encourages warming of both the ground and the near-surface air. Changes in snow depth, on the other hand, cool the soil where snow depths decrease, due to reduced insulation, but have comparatively little impact where snow depths deepen, such as in eastern Siberia (Fig. 7c, center panel). Why does the soil temperature response differ so distinctly for shallowing versus deepening snowpacks? This relates to the asymptotic nature of snow insulating capacity at deeper and deeper snow depths. This leads to an asymmetric snow insulation response to equivalent increases or decreases in snowpack depth with a 
Fig. 7 Maps of the difference in 2080-2099 conditions for HOLD_MW_DP-HOLD_DP (left column), TRND_DPHOLD_MW_DP (middle column), and TRND_DPHOLD_DP (right column). Variables shown are (a) shoulder season snow cover fraction (April, May, September, and October; AMSO), (b) winter snow depth (NDJFMA), and (c) annual max $T_{\text {soil }}$ at $1 \mathrm{~m}$ depth (a)

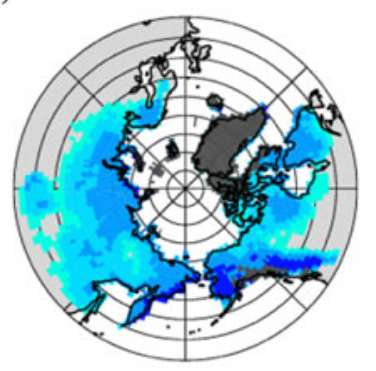

(b)

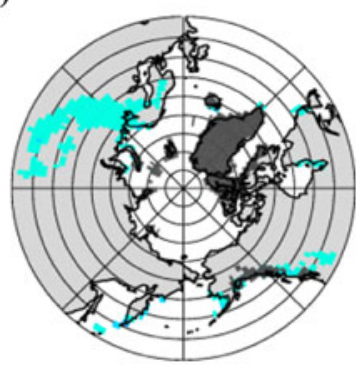

(c)

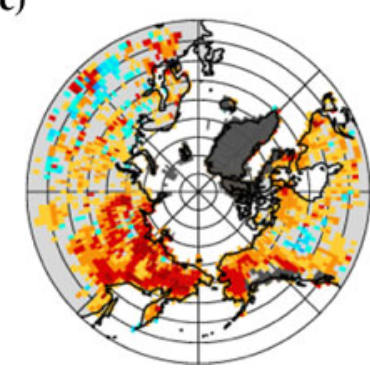

Snow cover fraction (AMSO)
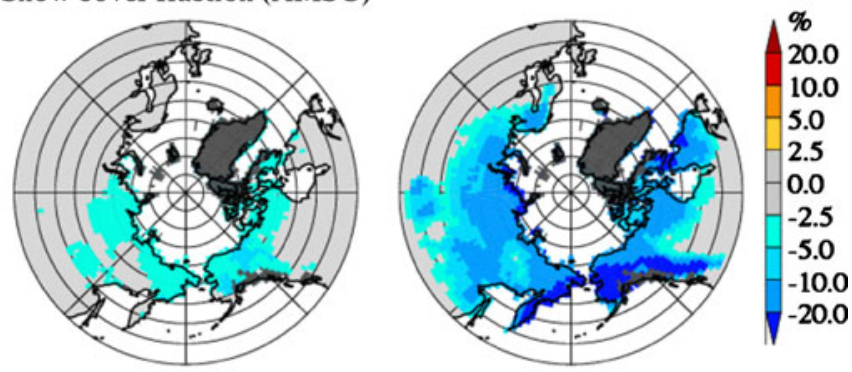

Snow Depth (NDJFMA)
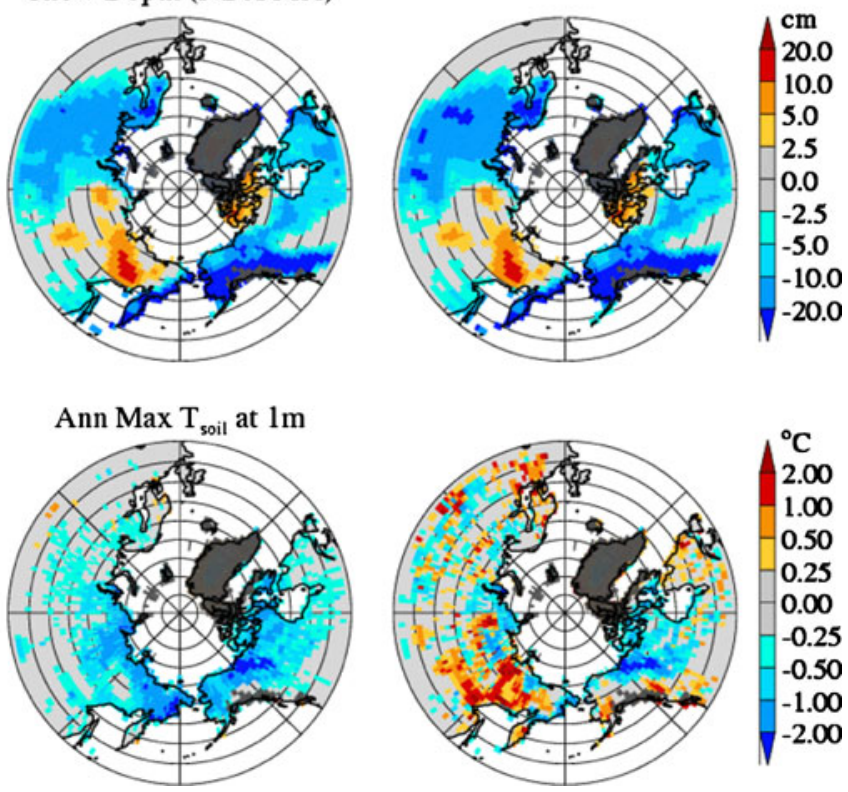

${ }^{\circ} \mathrm{C}$
2.00
1.00
0.50
0.25
0.00
-0.25
-0.50
-1.00
-2.00 shallowing depth having proportionally more impact (Zhang 2005).

The right hand panels in Fig. 7 represent the combined influence of projected snow depth and snow-season length changes on twentieth and twenty-first century soil temperature change. Snow depth changes tend to counteract nearsurface air warming whereas shorter snow-seasons enhance the warming. When the two effects are combined, we see that the relative soil temperature change at $1 \mathrm{~m}$ depth that can be attributed to snow changes is fairly evenly mixed with $26 \%$ of the non-glacier land area with a distinct snow season exhibiting relative warming $\left(\geq+0.25^{\circ} \mathrm{C}\right)$ and $25 \%$ of the area exhibiting relative cooling $\left(\leq-0.25^{\circ} \mathrm{C}\right)$.

\section{Discussion}

5.1 Relative influence of snow versus air temperature change on soil temperature trends

In the Introduction we note that a number of studies have concluded that, over the past several decades, soil temperature trends can be explained as much by trends in snow as in air temperature (Stieglitz et al. 2003; Osterkamp 2007a). It is interesting, therefore, to look at what the model tells us about the relative importance of snow versus air temperature trends on soil temperature change. We can do this directly using data from the experiments conducted for this study by comparing $T_{\text {soil }}$ change in TRND_FALL, where snow state changes evolve with climate change, with that in HOLD_DP, where snow conditions are held at climatological 1950-1969 levels. We calculate the percentage of the total change in $T_{\text {soil,max }}$ at $1 \mathrm{~m}$ depth $\left(\% \Delta T_{\text {soil,max }}\right.$ [SNOW]) that can be attributed to snow changes according to the following expression:

$$
\begin{aligned}
& \% \Delta T_{\text {soil,max }}[\text { SNOW }] \\
& =100 \frac{\Delta T_{\text {soil,max }}(\text { TRND_FALL })-\Delta T_{\text {soil, } \max }(\text { HOLD_DP })}{\Delta T_{\text {soil,max }}(\text { TRND_FALL })}
\end{aligned}
$$

where $\Delta$ refers to the difference across two 10 year periods (1990-1999 minus 1950-1959 for recent past and 20902099 minus 1950-1959 for future). Where the absolute 
value of $\% \Delta T_{\text {soil,max }}[\mathrm{SNOW}]$ is greater than $50 \%$, the influence of snow changes on soil warming is greater than or equal to that of air temperature. Conversely, where $\% \Delta T_{\text {soil,max }}[\mathrm{SNOW}]$ is near $0 \%$, the impact of air temperature change dominates.

The results of this calculation, plotted for every grid point with a distinct snow season, are shown in Fig. 8. For the recent 50 year period, snow state changes explain 50\% or more of the total $T_{\text {soil,max }}$ change over much of the terrestrial Arctic, which is consistent with the aforementioned prior assessments (Stieglitz et al. 2003; Osterkamp 2007a). By the end of the twenty-first century, however, the relative influence of snow state change diminishes. Instead, in most regions the century-scale soil temperature change is dominated by the influence of atmospheric warming, though there are pockets of strong snow influence, in this particular simulation, over far eastern Siberia and Alaska.

\subsection{Snow change as a predictor of soil temperature change}

Ideally, it would be useful if the prescribed snow experiments enabled us to derive a simple empirical function that could be used to quantitatively predict how $T_{\text {soil }}$ is influenced by future snow depth and snow season length changes across a range of potential snow state trajectories. On an individual basis, the sign or direction of SCF and SNWDP influences on $\Delta T_{\text {soil }}$ are consistent (e.g. Fig. 7c) but the magnitudes differ substantially across high latitude areas with seasonal snow cover. The strong spatial variability in the $\Delta \mathrm{SCF}-\Delta T_{\text {soil }}$ and $\Delta \mathrm{SNWDP}-\Delta T_{\text {soil }}$ relationships may be due to competing non-linear processes that together confound a simple diagnosis of snow's future contribution. Complicating factors likely include the non-linear snow depth/density-insulation relationship, the threshold of snow melt and soil thaw at $0^{\circ} \mathrm{C}$, spatial differences in overlying vegetation characteristics that affect the albedo response to snow depth change, and spatial variations in soil moisture and texture which influences the soil temperature response to snow forcing, among others. Therefore, a robust empirical expression cannot be attained.

\section{Summary}

In this study, we evaluate how projected changes in snowfall, snow depth, and snow season length can affect northern high-latitude soil temperature trends. In CCSM3, winter snowfall in northern regions increases by $10-40 \%$ over late twentieth century levels by 2100 , the snowpack shallows or deepens depending on location (more grid points experience shallowing than deepening), and the snow-season shortens from both ends $(-14 \pm 7$ days in spring, $+20 \pm 9$ days in autumn).

To isolate and evaluate the various influences of snow condition change on ground climate, we employ a series of offline prescribed-snow experiments with CLM, where snowfall, snow depth, and snow season length trends are imposed according to data obtained from a fully coupled CCSM3 simulation. Based on these experiments, we identify the following general influences of various aspects of snow condition change on twenty-first century soil temperature evolution:

- Increasing snowfall counters the predominantly shallowing influence of warmer winters and shorter snow seasons such that the model projects both shallowing and deepening snowpacks depending on location.

- The deeper relative snowpack as a result of increasing snowfall is effectively a soil warming agent, accounting for between 10 and $30 \%$ of total soil warming and $\sim 16 \%$ of the simulated twenty-first century decline in near-surface permafrost extent.

- A shortening of the snow-season enhances soil warming due to an extension of the spring/summer/autumn soil heating period.
Fig. 8 Percentage of $\Delta T_{\text {soil,max }}$ at $1 \mathrm{~m}$ depth that can be attributed to snow state trends. See text for expression (Eq. 7) used to calculate this field. Results from two periods, 1990-1999 and 2090-2099, are shown, both relative to 1950-1959
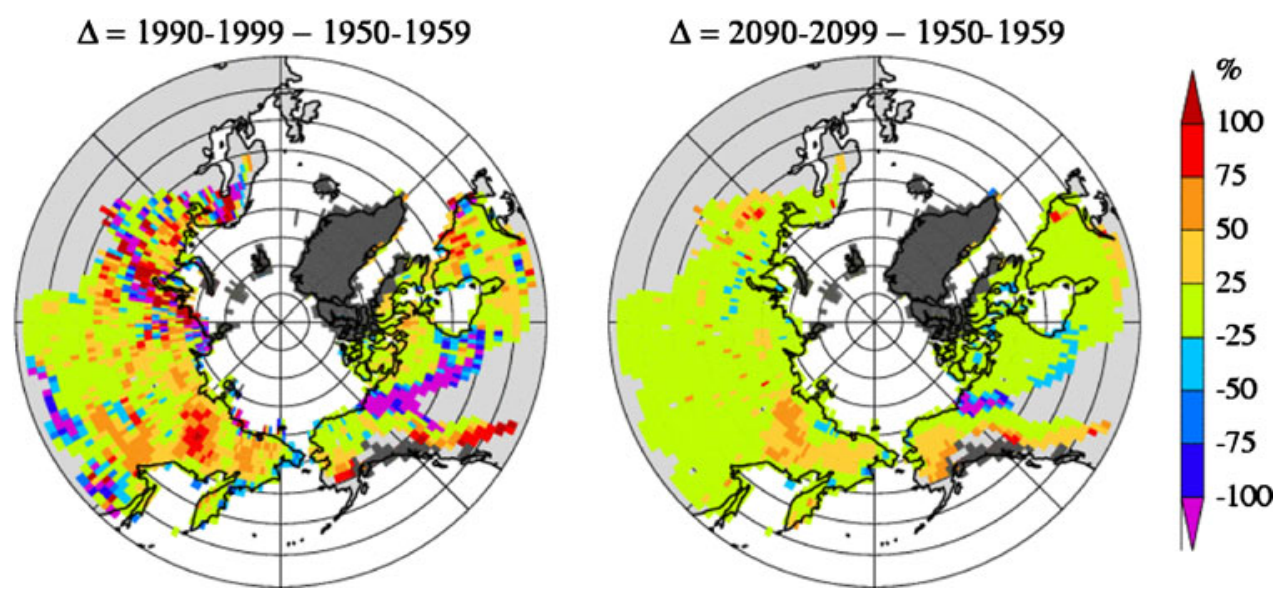
- A shallowing of the snowpack impedes soil warming due to weaker winter insulation from cold atmospheric air.

- A deepening of the snowpack has comparatively less influence due to saturation of the snow insulation effect at deeper snow depths.

- When considered together, the generally opposing influences of snow-season length and snow depth changes result in a combined impact of either enhanced soil warming (exacerbating the change related to surface air warming), or relative soil cooling (offsetting some of the increased air temperature influence), depending on the specific snow state and climate change experienced at a particular location.

- Snow and air temperature change exert roughly equivalent forcing on soil temperature change in this modeling system, depending again on location, over the last 50 years of the twentieth century, but the relative influence of snow change diminishes under the strong projected warming of the twenty-first century.

Acknowledgments We would like to thank two anonymous reviewers for their constructive comments on this paper. This research was supported by the Office of Science (BER), U. S. DOE, Cooperative Agreement No. DE-FC02-97ER62402 and NSF grants ARC0229769, ARC-0531040 and ARC-0732986. NCAR is sponsored by NSF.

\section{References}

Cassano JJ, Uotila P, Lynch AH, Cassano EN (2007) Predicted changes in synoptic forcing of net precipitation in large Arctic river basins during the 21 st century. J Geophys Res 112:G04S49. doi: $10.1029 / 2006 J G 000332$

Chapman WL, Walsh JE (2007) Simulations of Arctic temperature and pressure by global coupled models. J Clim 20:609-632. doi: 10.1175/JCLI4026.1

Collins WD, Bitz CM, Blackmon ML, Bonan GB, Bretherton CS, Carton JA, Chang P, Doney SC, Hack JJ, Henderson TB, Kiehl JT, Large WG, McKenna DS, Santer BD, Smith RD (2006) The Community Climate System Model Version 3 (CCSM3). J Clim 19:2122-2143. doi:10.1175/JCLI3761.1

Dye DG (2002) Variability and trends in the annual snow-cover cycle in Northern Hemisphere land areas, 1972-2000. Hydrol Process 16:3065-3077. doi:10.1002/hyp.1089

Goodrich LE (1982) The influence of snow cover on the ground thermal regime. Can Geotech J 19:421-432

Jordan R (1991) A one-dimensional temperature model for a snow cover: technical documentation for SNTHERM.89. Report No. Special Report 91-16. U.S. Army Cold Regions Research and Engineering Laboratory, Boulder

Lawrence DM, Slater AG (2005) A projection of severe near-surface permafrost degradation during the 21 st century. Geophys Res Lett 24:L24401. doi:10.1029/2005GL025080

Lawrence DM, Slater AG (2008) Incorporating organic soil into a global climate model. Clim Dyn 30. doi:10.1007/s00382-0070278-1
Lawrence DM, Thornton PE, Oleson KW, Bonan GB (2007) Partitioning of evaporation into transpiration, soil evaporation, and canopy evaporation in a GCM: impacts on land-atmosphere interaction. J Hydrometall 8:862-880. doi:10.1175/JHM596.1

Lawrence DM, Slater AG, Romanovsky VE, Nicolsky DJ (2008a) The sensitivity of a model projection of near-surface permafrost degradation to soil column depth and inclusion of soil organic matter. J Geophys Res 113:F02011. doi:10.1029/2007JF000883

Lawrence DM, Slater AG, Tomas RA, Holland MM, Deser C (2008b) Accelerated Arctic land warming and permafrost degradation during rapid sea ice loss. Geophys Res Lett 35:L11506. doi: 10.1029/2008GL033985

Lemke P, Ren J, Alley RB, Allison I, Carrasco J, Flato G, Fujii Y, Kaser G, Mote P, Thomas RH, Zhang T (2007) Observed changes in snow, ice and frozen ground. In: Solomon S, Qin D, Manning M, Chen Z, Marquis M, Averyt KB, Tignor M, Miller HL (eds) Climate change 2007: the physical science basis contribution of Working Group I to the fourth assessment report of the intergovernmental panel on climate change. Cambridge University Press, Cambridge

Meehl GA, Washington WM, Santer BD, Collins WD, Arblaster JM, $\mathrm{Hu}$ A, Lawrence DM, Teng H, Buja LE, Strand WG (2006) Climate change in the 20th and 21st centuries and climate change commitment in the CCSM3. J Clim 19:2597-2616. doi: 10.1175/JCLI3746.1

Meehl GA, Covey C, Delworth T, Latif M, McAvaney B, Mitchell JFB, Stouffer RJ, Taylor KE (2007a) The WCRP CMIP3 multimodel dataset - a new era in climate change research. Bull Am Meteorol Soc 88:1383-1394. doi:10.1175/BAMS-88-9-1383

Meehl GA, Stocker TF, Collins WD, Friedlingstein P, Gaye AT, Gregory JM, Kitch A, Knutti R, Murphy JM, Noda A, Raper SCB, Watterson IG, Weaver AJ, Zhao Z-C (2007b) Global climate projections. In: Solomon S, Qin D, Manning M, Chen Z, Marquis M, Averyt KB, Tignor M, Miller HL (eds) Climate change 2007: the physical science basis contribution of Working Group I to the fourth assessment report of the intergovernmental panel on climate change. Cambridge University Press, Cambridge

Nicolsky DJ, Romanovsky VE, Alexeev VA, Lawrence DM (2007) Improved modeling of permafrost dynamics in a GCM landsurface scheme. Geophys Res Lett 34:L08501. doi:10.1029/ 2007GL029525

Oleson KW, Dai Y, Bonan G, Dickinson RE, Dirmeyer PA, Hoffman F, Houser P, Levis S, Niu G-Y, Thornton P, Vertenstein M, Yang Z-L, Zeng X (2004) Technical description of the Community Land Model (CLM). report no. NCAR Tech. Note TN-461 + STR. National Center for Atmospheric Research, Boulder

Oleson KW, Niu G-Y, Yang Z-L, Lawrence DM, Thornton PE, Lawrence PJ, Stöckli R, Dickinson RE, Bonan GB, Levis S, Dai A, Qian T (2008) Improvements to the Community Land Model and their impact on the hydrological cycle. J Geophys Res 113:G01021. doi:10.1029/2007JG000563

Osterkamp T (2007a) Causes of warming and thawing of permafrost in Alaska. EOS 88:522-523. doi:10.1029/2007EO480002

Osterkamp $\mathrm{T}$ (2007b) Characteristics of the recent warming of permafrost in Alaska. J Geophys Res 112:F02S02. doi: 10.1029/2006JF000578

Osterkamp TE, Romanovsky VE (1999) Evidence for warming and thawing of discontinuous permafrost in Alaska. Permafr Periglac Proc 10:17-37. doi:10.1002/(SICI)1099-1530(199901/03)10:1< c17::AID-PPP303>3.0.CO;2-4

Räisänen J (2008) Warmer climate: less or more snow? Clim Dyn 30, doi:10.1007/s00382-007-0289-y

Romanovsky VE (2001) Daily average soil, air and ground temperatures at Ivotuk, Alaska. National Snow and Ice Data Center, Boulder. http://data.eol.ucar.edu/codiac/dss/id=46.217 
Slater AG, Bohn TJ, McCreight JL, Serreze MC, Lettenmaier DP (2007) A multi-model simulation of pan-arctic hydrology. J Geophys Res 112:G04S45. doi:10.1029/2006JG000303

Stendel M, Christensen JH (2002) Impact of global warming on permafrost conditions in a coupled GCM. Geophys Res Lett 13. doi:10.1029/2001GL014345

Stieglitz M, Ducharne A, Koster R, Suarez M (2001) The impact of detailed snow physics on the simulation of snow cover and subsurface thermodynamics at continental scales. J Hydrometall 2:228-242. doi:10.1175/1525-7541(2001)002<0228:TIODSP $>$ 2.0.CO;2

Stieglitz M, Dery SJ, Romanovsky VE, Osterkamp TE (2003) The role of snow cover in the warming of arctic permafrost. Geophys Res Lett 30. doi:10.1029/2003GL017337

Stöckli R, Lawrence DM, Niu G-Y, Oleson KW, Thornton PE, Yang Z-L, Bonan GB, Denning AS, Running SW (2008) The use of Fluxnet in the Community Land Model development. J Geophys Res 113. doi:10.1029/2007JG000562
Sturm M, Schimel J, Michaelson G, Welker JM, Oberbauer SF, Liston GE, Fahnestock J, Romanovsky VE (2005) Winter biological processes could help convert arctic tundra to shrubland. Bioscience 55:17-26. doi:10.1641/0006-3568(2005)055 [0017:WBPCHC]2.0.CO;2

Zhang T (2005) Influence of the seasonal snow cover on the ground thermal regime: an overview. Rev Geophys 43:RG4002. doi: 10.1029/2004RG000157

Zhang T, Barry RG, Gilichinsky D, Bykhovets SS, Sorokovikov VA, Ye JP (2001) An amplified signal of climatic change in soil temperatures during the last century at Irkutsk, Russia. Clim Change 49:41-76. doi:10.1023/A:1010790203146

Zhang Y, Chen WJ, Riseborough DW (2008) Transient projections of permafrost distribution in Canada during the 21 st century under scenarios of climate change. Global Planet Change 60:443-456. doi:10.1016/j.gloplacha.2007.05.003 